\title{
А.В. Пиюк \\ ДОСУДЕБНОЕ СОГЛАШЕНИЕ О СОТРУДНИЧЕСТВЕ: ПРОБЛЕМЫ И ПУТИ ИХ РЕШЕНИЯ
}

\begin{abstract}
В статье анализируются положения действующего уголовно-прочессуального законодательства, регулирующего вынесение приговора при заключении досудебного соглашения о сотрудничестве, особое внимание уделяется вопросам истинности приговора, вынесенного в особом порядке судебного разбирательства, а также проблеме прочессуального статуса сотрудничающего лица. В иелях вынесения обоснованного справедливого приговора предлагается исключить из УПК РФ положение о выделении уголовных дел в отношении сотрудничающих лиц в отдельное производство, а также норму, запрещающую обжаловать приговор по мотивам его несоответствия фактическим обстоятельствам уголовного дела.

Ключевые слова: уголовный процесс; упрощенное уголовное судопроизводство; соглаиение о сотрудничестве; лица, сотрудничающие со следствием; сделка в уголовном nроиессе.
\end{abstract}

С начала реформы законодательства РФ, с принятием Концепции судебной реформы традиционно декларировалось, что суд в Российской Федерации - орган правосудия, что он независим и беспристрастен. Как известно, в ч. 3 ст. 15 УПК РФ закреплено, что суд не является органом преследования, не выступает на стороне обвинения или стороне защиты, он лишь создает необходимые условия для исполнения сторонами их процессуальных обязанностей и осуществления их прав.

Вместе с тем частью 4 статьи 317.7 УПК РФ, определяющей порядок проведения судебного заседания и постановления приговора в отношении подсудимого, с которым заключено досудебное соглашение о сотрудничестве, установлено, что судом при рассмотрении дела в особом порядке должны быть исследованы: 1) характер и пределы содействия подсудимого следствию в раскрытии и расследовании преступления, изобличении и уголовном преследовании других соучастников преступления, розыске имущества, добытого в результате преступления; 2) значение сотрудничества с подсудимым для раскрытия и расследования преступления, изобличения и уголовного преследования других соучастников преступления, розыска имущества, добытого в результате преступления; 3) преступления или уголовные дела, обнаруженные или возбужденные в результате сотрудничества с подсудимым; 4) степень угрозы личной безопасности, которой подвергались подсудимый в результате сотрудничества со стороной обвинения, его близкие родственники, родственники и близкие лица; 5) обстоятельства, характеризующие личность подсудимого, и обстоятельства, смягчающие или отягчающие наказание.

В вышеприведенных нормах не идет речь ни о доказанности преступления, совершение которого вменено подсудимому, ни даже об отсутствии у судьи каких-либо сомнений. Главным является наличие ходатайства о заклю- 
чении соглашения, заключение самого соглашения и соблюдение порядка производства по такой процедуре, а также получение органами расследования информации в отношении иных лиц, в реальности или предположительно совершивших преступления, а также «удостоверение прокурором правдивости сведений, сообщенных обвиняемым».

При этом в п. 16 постановления Пленума Верховного Суда РФ от 28 июня 2012 г. № 16 «О практике применения судами особого порядка судебного разбирательства уголовных дел при заключении досудебного соглашения о сотрудничестве» обращено внимание судов на то, что в судебном разбирательстве по уголовному делу в отношении подсудимого, с которым заключено досудебное соглашение о сотрудничестве, суд не проводит в общем порядке исследование и оценку доказательств, собранных по уголовному делу (ч. 5 ст. 316 УПК РФ), однако далее Пленум разъяснил, что «с учетом положений части 6 статьи 317.7 УПК РФ о том, что описательно-мотивировочная часть обвинительного приговора должна содержать описание преступного деяния, в совершении которого обвиняется подсудимый, суд постановляет обвинительный приговор и назначает подсудимому наказание, только если придет к выводу, что обвинение, с которым согласился подсудимый, является обоснованным и подтверждается доказательствами, собранными по делу». Пунктом 23 Постановления Пленума Верховного Суда РФ № 16 декларировано также, что глава 40.1 УПК РФ не содержит норм, запрещающих принимать по делу, рассматриваемому в особом порядке в связи с досудебным соглашением о сотрудничестве, иные, кроме обвинительного приговора, судебные решения. В частности, Пленум указал, что содеянное подсудимым может быть переквалифицировано, а уголовное дело прекращено судом (в связи с изменением уголовного закона, истечением сроков давности, актом об амнистии и т.д.), если для этого не требуется исследования собранных по делу доказательств и фактические обстоятельства при этом не изменяются [1].

В реальности случаев прекращения производства по делу либо вынесения оправдательного приговора при рассмотрении дела в особом порядке нам не встречалось, гипотетически это возможно, если суд усмотрит какиелибо грубейшие нарушения, к примеру, если обвиняемый вообще не подлежит уголовной ответственности в силу того, что он не является субъектом преступления, которое ему вменяется, однако подобные нарушения все же крайне редки, в действующей же конструкции подсудимый может рассчитывать только на прекращение особого порядка и переход к рассмотрению дела в общем порядке, где суд может принять любое решение, вплоть до оправдательного приговора, либо, учитывая разъяснения Верховного Суда РФ, на применение положений главы 40 УПК РФ, если имеются все необходимые для этого условия.

К заслугам высшей судебной инстанции следует отнести и требования выносить обоснованные решения, подтверждающиеся доказательствами (при отсутствии в УПК механизма их исследования), и разъяснение о возможности постановления иных, кроме обвинительных приговоров, решений, и фактическое установление требования проверять выполнение условий для рассмотрения дела в особом порядке, изложенных в ч. 2 ст. 317.6 УПК РФ, в судебном заседании, а не при непроцессуальном изуче- 
нии материалов уголовного дела, как это установлено положениями УПК РФ. Пленум в данных случаях истолковал закон, в нормах действующего УПК РФ нет положений, из которых подобное толкование следует, однако возможности Верховного Суда РФ прямо ограничены самим уголовнопроцессуальным законом, основные недостатки кодекса Верховный Суд преодолеть не может.

При изучении норм главы 40.1 УПК РФ создается стойкое впечатление, что суд, по мнению законодателя, при рассмотрении дела в порядке главы 40.1 УПК РФ не призван осуществлять правосудие. Законодатель ничего не упоминает о том, что суд должен изучить доказательства вины подсудимого в инкриминируемом ему деянии, он призван лишь проверить и выяснить, в чем подсудимый оказал органам расследования содействие.

В работах, посвященных проблематике главы 40.1 УПК РФ, встречаются интересные выводы. Так, Н.А. Дудина указала, что «закрепленный в УПК РФ особый порядок принятия судебного решения при заключении досудебного соглашения о сотрудничестве инициировал появление новой формы осуществления правосудия по уголовным делам, где суд фактически выполняет контрольную функцию за законностью деятельности органов предварительного следствия в случае заключения досудебного соглашения о сотрудничестве» [2. С. 128]. Представляется, что говорить о появлении «новой формы осуществления правосудия» в данном случае нельзя, однако трудно не согласиться с тем, что правосудием порядок, закрепленный в главе 40.1 УПК РФ, не является. При использовании положений данной главы суд может только повторить в приговоре то, что ему предоставили следователь и прокурор, согласно ч. 6 ст. 317.7 УПК РФ описательно-мотивировочная часть приговора должна содержать лишь описание деяния (без анализа доказательств) и «выводы суда о соблюдении подсудимым условий и выполнении обязательств, предусмотренных заключенным с ним досудебным соглашением о сотрудничестве». А дело ли это суда? При применении формулировок, подобных вышеприведенной, создается впечатление, что суд призван «легализовать» соглашение, а не разрешить вопрос о виновности либо невиновности подсудимого, при этом ему предлагается принять на себя всю ответственность за предыдущие действия и решения следователя и прокурора. Полагаем, что при отсутствии закрепленной законодательно обязанности коголибо и когда-либо исследовать вопросы о виновности и доказанности преступления, в совершении которого гражданин признался, вполне реальна возможность осуждения в особом порядке невиновных лиц, а также и лиц, в отношении которых даны показания сотрудничающими.

В литературе высказано мнение, что недостатки соглашения о сотрудничестве вызваны тем, что в их заключении не участвует суд [3]. Утверждается, что для их устранения «было бы правильным передать полномочия прокурора по заключению досудебного соглашения о сотрудничестве суду, как участнику уголовного судопроизводства, наделенному полномочиями... по созданию необходимых условий для осуществления сторонами их процессуальных обязанностей и предоставленных им прав» [4. С. 25]. 
Подобные предложения представляются крайне опасными и вредными, не соответствующими роли суда как органа правосудия, а их реализация способна разрушить то позитивное, что еще осталось в уголовном судопроизводстве РФ.

Непосредственно после принятия УПК РФ М.К. Свиридов, проанализировав нормы УПК РФ, регламентирующие общий и особый порядки судебного разбирательства, указал, что кодекс внутренне противоречив даже с точки зрения определения целей и задач доказывания и допускает установление как материальной, так и формальной (юридической) истин [5. С. 3].

Если задачами введения института рассмотрения уголовного дела в особом порядке является, как указывал законодатель в Концепции судебной реформы и как считают ученые-процессуалисты [6; 7. С. 17], обеспечение быстроты судопроизводства, экономия процессуальных средств, «разгрузка» перегруженной работой судебной системы, утрируя, можно сделать вывод, что дела подсудимых, которые выбирают общую процедуру, суд призван рассмотреть качественно, приняв обоснованное судебное решение, дела же подсудимых, выбравших упрощенные судебные порядки, он должен рассмотреть быстро.

Очевидно, что в настоящее время в Российской Федерации фактически имеется два принципиально различных вида обвинительных приговоров уголовного суда: приговор, постановленный в общем, обычном порядке, и судебный акт, вынесенный судом в порядке главы 40 УПК РФ. То, что эти акты, называемые одинаково - «приговоры», имеют различную природу, было понятно сразу после введения УПК РФ, однако законодательно «различие» было констатировано лишь с принятием Федерального закона от 29 июня 2015 г. № 191-Ф3 «О внесении изменения в статью 90 Уголовнопроцессуального кодекса Российской Федерации», которым в ст. 90 УПК РФ внесено изменение, устанавливающее, что «обстоятельства, установленные вступившим в законную силу приговором, за исключением приговора, постановленного судом в соответствии со статьей 226.9, 316 или 317.7 настоящего Кодекса, либо иным вступившим в законную силу решением суда... признаются судом, прокурором, следователем, дознавателем без дополнительной проверки» [8]. Кроме того, в УПК РФ закреплены и положения ст. 317 УПК РФ о недопустимости обжалования приговора, вынесенного в особом порядке, по мотивам несоответствия выводов суда фактическим обстоятельствам дела, т.е. законодатель сознательно допускает вынесение подобного акта, не соответствующего реальности.

Постулатом российского уголовного процесса всегда являлось положение, что приговор суда должен быть законным, обоснованным, правосудным, лишь такой судебный акт способен вызвать уважение к государству и к суду. Приговор, не отвечающий объективной реальности, противоречащий обстоятельствам совершенного деяния не есть приговор, не есть акт правосудия. Запрещая обжаловать приговор по мотивам его несоответствия реальности, как представляется, законодатель дискредитирует саму идею правосудия, допуская, что лицо может быть осуждено необоснованно. 
Много вопросов вызывает и процессуальный статус лица, заключившего соглашение о сотрудничестве и дающего показания в отношении его соучастников (действительных либо предполагаемых). В литературе высказаны даже мнения, что такое лицо является по основному делу, рассматриваемому в отношении иных лиц, свидетелем, для допустимости показаний которого его следует предупреждать об уголовной ответственности за отказ от дачи показаний и за дачу заведомо ложных показаний [9].

И.Я. Фойницкий отмечал, что судебная практика богата многочисленными примерами неверных признаний, объясняемых различными причинами, указывая, что «ложные признания даются подсудимым под влиянием принуждения, давления... которое может привести его к неверному признанию, благодаря тягостному положению его на предварительном следствии» [9. С. 268]. Еще более осторожно призывалось относиться к оговору, рекомендуя обращать тщательное внимание на то, «не заинтересован ли сам подсудимый в том, чтобы его оговор был принят, т.е. не делается ли он для самооправдания и сваливания вины на другого; и в этих случаях нередко, чем такой оговор полнее и убедительнее, тем он более возбуждает подозрения» 9 . C. 254].

Представляется, что можно предложить решение имеющихся в уголовном судопроизводстве современной России проблем.

Поскольку поведение лица, привлекаемого к уголовной ответственности, диспозитивно, запрещать ему сотрудничать с кем бы то ни было, в том числе с органами предварительного расследования, нельзя. Вместе с тем очевидно, что механизм такого сотрудничества, закрепленный в главе 40.1 УПК РФ, крайне неудачен и содержит риск необоснованного осуждения как самого «сотрудничающего», так и в особенности лиц, в отношении которых он дает показания.

В большинстве своем недостатки соглашения о сотрудничестве вызваны порождением требования п. 4 абз. 1 ст. 154 УПК РФ о выделении в отдельное производство уголовных дел в отношении сотрудничающих лиц.

Обращает на себя внимание, что подавляющая часть опрашиваемых практических работников, сталкивающихся с использованием соглашения о сотрудничестве, не видит смысла в выделении дела в отношении лица, с которым заключено соглашение, в отдельное производство. Так считают 87, 7\% опрошенных судей, 93,69\% прокуроров и $84,18 \%$ защитников. При этом около 95\% опрошенных среди всех субъектов судопроизводства не знают и не слышали о случаях угроз, насилия и т.д. в отношении лиц, с которыми заключены соглашения о сотрудничестве, а также не видят смысла в хранении каких-либо документов по уголовному делу в отдельном конверте, так как все предполагаемые соучастники преступления и все лица, которые сотрудничают со следствием, хорошо известны и их соучастникам, и их родственникам. Наиболее частая реакция на заключение сделки, встречающаяся в более чем $80 \%$ случаев, не угрозы и не действия по нейтрализации сотрудничающего, а подача аналогичного ходатайства соучастника с просьбой заключить сделку также и с ним (!). Представляется, что и предварительное следствие, и судебное разбирательство при едином расследовании и одномоментном рассмотрении дела позволяют установить роль каждого из соучастников 
точнее и полнее, чем при выделении дел. Напротив, выделение уголовного дела в отношении лица, заключившего соглашение о сотрудничестве, и рассмотрение его раздельно с уголовным делом по обвинению иных лиц способствуют возникновению множества коллизий и сложностей.

Для обеспечения вынесения законного, обоснованного приговора было бы логично исключить из уголовно-процессуального закона положения п. 4 абз. 1 ст. 154 УПК РФ о выделении уголовного дела в отношении сотрудничающих со следствием лиц в отдельное производство. Лица, желающие сотрудничать со следствием и давать показания в отношении соучастников преступления, должны делать это в рамках общего, обычного порядка разрешения уголовного дела, без выделения дел в отношении их в отдельное производство. Для поощрения таких лиц в УК и УПК РФ одновременно следует сохранить преференции по наказанию, действующие в настоящее время в отношении сотрудничающих со следствием лиц. Кроме того, необходимо исключить из УПК РФ дискредитирующее идею правосудия положение о недопустимости обжалования приговора уголовного суда по мотивам его несоответствия фактическим обстоятельствам уголовного дела.

\section{Лuтература}

1. О практике применения судами особого порядка судебного разбирательства уголовных дел при заключении досудебного соглашения о сотрудничестве: постановление Пленума ВС РФ от 28 июня 2012 г. № 16 // Российская газета. 2012. 11 июля. № 156.

2. Дудина Н.A. Порядок производства при заключении досудебного соглашения о сотрудничестве как процессуальная форма деятельного раскаяния: дис. ... канд. юрид. наук. Томск, 2015. $226 \mathrm{c.}$

3.Шаталов А.С. //Журнал российского права. 2010. № 5. С. 23-26.

4. Кубрикова М.Е. Актуальные вопросы института досудебного соглашения о сотрудничестве: дис. .... канд. юрид. наук. Челябинск, 2013. 232 с.

5. Свиридов M.K. Состязательность и установление истины в уголовном судопроизводстве// Правовые проблемы укрепления российской государственности / под ред. Ю.К. Якимовича. Томск, 2002. Ч. 10 С. 3-6.

6. Шмарев А.И. Особый порядок судебного разбирательства (вопросы теории и практики): дис. ... канд. юрид. наук. Ижевск, 2004. 206 с.

7. Монид М.В. Особый порядок принятия судебного решения при согласии обвиняемого с предъявленным обвинением: дис. ... канд. юрид. наук. Иркутск, 2007.

8. Федеральный закон № 191-ФЗ от 29 июня 2015 г. // Собрание законодательства РФ. 2015. № 27. Ст. 3982.

9. Фойниикий И.Я. Курс уголовного судопроизводства. СПб.: Альфа, 1996. Т. 2. 521 с.

Piyuk Alexey $V$. Megion City Court (Nizhnevartovsk, Russian Federation)

\section{PRETRIAL COOPERATION AGREEMENT: PROBLEMS AND SOLUTIONS}

Keywords: criminal procedure; simplified criminal procedure; cooperation agreement; person cooperating with the investigation; plea bargain in criminal proceedings.

Currently, the Russian Federation has two fundamentally different types of "guilty" verdicts of the criminal court: sentences according to the standard procedure and judicial acts by the court according to Chapters 40 and 40.1 of the Criminal Procedure Code of the Russian Federation (RF CPC).

The study of the norms of Chapter 40.1 of the RF CPC gives the impression that the court, in view of the legislator, is not intended to administer justice when hearing cases according to these norms. Article 90 of the RF CPC states that circumstances established by a final and binding court verdict according to Chapters 40 and 40.1 of the RF CPC do not have a prejudicial nature. The provisions of Art. 317 on the inadmissibility of the appeal of the court verdict, delivered according to 
the special procedure, based on the non-compliance of court findings with the factual circumstances of the case are also enshrined in the RF CPC; thus, the legislator consciously allows the imposition of an act non-complying with the reality.

However, the sentence non-complying with the objective reality, contrary to the circumstances of the offense, is not an act of justice.

Since the behavior of the prosecuted person is discretionary, it is impossible to forbid him to cooperate with the preliminary investigation bodies. However, the mechanism for such cooperation as enshrined in Chapter 40.1 of the RF CPC, is inefficient and bears the risk of unfounded judgment of both the "cooperating" person and, in particular, persons he testifies about.

A disadvantage of a cooperation agreement is a result of the requirement of Part 4 Paragraph 1 Art. 154 of the RF CPC to separate criminal cases that involve cooperating persons into separate proceedings. The preliminary investigation and trial in a single investigation and one-stage consideration of the case, when the totality of the evidence in the case is examined in the same process, allow establishing the role of each of the accomplices more precisely and fully than in the separation of cases.

In order to deliver a legal, justified verdict it would be logical to exclude the provision of Part 4 Paragraph 1 Art. 154 of the RF CPC on separating criminal cases that involve cooperating persons into separate proceedings. Persons wishing to cooperate with the investigation and testify against accomplices must do so within the framework of the general, standard procedure of the criminal trial, without separating cases against them into a separate proceeding. To encourage such persons, the RF Criminal Code and the RF Criminal Procedure Code should preserve the preferences on punishment currently in force in respect of persons cooperating with the investigation. In addition, it is necessary to exclude the provision on the inadmissibility of the appeal of the court verdict based on the noncompliance of court findings with the factual circumstances of the case from the RF CPC as it discredits the idea of justice.

\section{References}

1. Rossiyskaya gazeta. (2012) O praktike primeneniya sudami osobogo poryadka sudebnogo razbiratel'stva ugolovnykh del pri zaklyuchenii dosudebnogo soglasheniya o sotrudnichestve: postanovlenie Plenuma VS RF ot 28 iyunya 2012 g. № 16 [On application by courts of a special order of the trial of criminal cases at the conclusion of the pre-trial agreement on cooperation: Resolution № 16 of the Plenum of the RF Armed Forces of June 28, 2012]. 11th June. 156.

2. Dudina, N.A. (2015) Poryadok proizvodstva pri zaklyuchenii dosudebnogo soglasheniya o sotrudnichestve kak protsessual'naya forma deyatel'nogo raskayaniya [The procedure at the conclusion of the pre-trial agreement on cooperation as a procedural form of active repentance]. Law Cand. Diss. Tomsk.

3. Shatalov, A.S. (2010) Zaklyuchenie dosudebnogo soglasheniya o sotrudnichestve: pravovaya reglamentatsiya, dostoinstva $i$ nedostatki [Conclusion of the pretrial agreement on cooperation: legal regulation, advantages and disadvantages]. Zhurnal rossiyskogo prava - Journal of Russian Law. 5. pp. 23-26.

4. Kubrikova, M.E. (2013) Aktual'nye voprosy instituta dosudebnogo soglasheniya o sotrudnichestve [Topical issues of the institute pre-trial agreement on cooperation]. Law Cand. Diss. Chelyabinsk.

5. Sviridov, M.K. (2002) Sostyazatel'nost' i ustanovlenie istiny v ugolovnom sudoproizvodstve [The adversarial system and the truth in the criminal trial]. In: Yakimovich, Yu.K. (ed.) Pravovye problemy ukrepleniya rossiyskoy gosudarstvennosti [Legal problems of strengthening of Russian statehood]. Tomsk: Tomsk State University. pp. 3-6.

6. Shmarev, A.I. (2004) Osobyy poryadok sudebnogo razbiratel'stva (voprosy teorii i praktiki) [Special order of the trial (theory and practice)]. Law Cand. Diss. Izhevsk.

7. Monid, M.V. (2007) Osobyy poryadok prinyatiya sudebnogo resheniya pri soglasii obvinyaemogo s pred"yavlennym obvineniem [A special procedure for the adoption of the court decision when the defendant agrees with the accusation]. Law Cand. Diss. Irkutsk.

8. Russian Federation. (2015) Federal'nyy zakon № 191-FZ ot 29 iyunya 2015 g. [Federal Law № 191-FZ of June 29, 2015]. Sobranie zakonodatel'stva RF - Legislation bulletin of the Russian Federation. 27. Art. 3982.

9. Foynitskiy, I.Ya. (1996) Kurs ugolovnogo sudoproizvodstva [Criminal proceedings]. Vol. 2. St. Petersburg: Al'fa. 